University of Nebraska - Lincoln

DigitalCommons@University of Nebraska - Lincoln

Publications from USDA-ARS / UNL Faculty

U.S. Department of Agriculture: Agricultural

Research Service, Lincoln, Nebraska

2010

Yield, Quality, and Water and Nitrogen Use of Durum and Annual Forages in Two-Year Rotations

A. W. Lenssen

USDA-ARS, andy.lenssen@ars.usda.gov

S. D. Cash

Montana State University - Bozeman

P. G. Hatfield

Montana State University - Bozeman, hatfield@montana.edu

U. M. Sainju

USDA-ARS

W. R. Grey

Montana State University - Bozeman

See next page for additional authors

Follow this and additional works at: https://digitalcommons.unl.edu/usdaarsfacpub

Lenssen, A. W.; Cash, S. D.; Hatfield, P. G.; Sainju, U. M.; Grey, W. R.; Blodgett, S. L.; Goosey, H. B.; Griffith, D. A.; and Johnson, G. D., "Yield, Quality, and Water and Nitrogen Use of Durum and Annual Forages in TwoYear Rotations" (2010). Publications from USDA-ARS / UNL Faculty. 1385.

https://digitalcommons.unl.edu/usdaarsfacpub/1385

This Article is brought to you for free and open access by the U.S. Department of Agriculture: Agricultural Research Service, Lincoln, Nebraska at DigitalCommons@University of Nebraska - Lincoln. It has been accepted for inclusion in Publications from USDA-ARS / UNL Faculty by an authorized administrator of DigitalCommons@University of Nebraska - Lincoln. 


\section{Authors}

A. W. Lenssen, S. D. Cash, P. G. Hatfield, U. M. Sainju, W. R. Grey, S. L. Blodgett, H. B. Goosey, D. A. Griffith, and G. D. Johnson 


\title{
Yield, Quality, and Water and Nitrogen Use of Durum and Annual Forages in Two-Year Rotations
}

\author{
A. W. Lenssen,* S. D. Cash, P. G. Hatfield, U. M. Sainju, W. R. Grey, \\ S. L. Blodgett, H. B. Goosey, D. A. Griffith, and G. D. Johnson
}

\begin{abstract}
Annual spring-seeded forage crops use less water than cereal grains, including durum (Triticum turgidum L. var. durum), and may be suitable to replace summer fallow. We conducted an experiment from 2002 through 2006 comparing yield, quality, and water and $\mathrm{N}$ use of durum and three annual forages, barley (Hordeum vulgare L.), barley interseeded with pea [Pisum sativum L. ssp. arvense (L.) Poir.], and foxtail millet [Setaria italica (L.) Beauv.] in 2-yr rotations. Durum in rotation with summer fallow and alfalfa (Medicago sativa L.) were included. Averaged over $5 \mathrm{yr}$, alfalfa had higher forage yield and quality, water use, and $\mathrm{N}$ accumulation compared to annual forages. Annual forages had similar preplant and postharvest soil water contents, but barley and barley-pea had higher yields and water use compared to millet. Barley-pea intercrop had superior forage crude protein (CP), neutral detergent fiber (NDF) and N accumulation compared to barley and millet, but acid detergent fiber (ADF) and nitrogen recovery index (NRI) were similar among annual forages. Averaged over $4 \mathrm{yr}$, preplant soil water and residual $\mathrm{N}$ content were greater for durum following fallow than for durum following annual forages, resulting in reduced fertilizer $\mathrm{N}$ requirement and greater yield, water use, grain $\mathrm{N}$ accumulation and $\mathrm{NRI}$ following fallow. Replacing summer fallow with annual forages reduced durum grain yield by $727 \mathrm{~kg} \mathrm{ha}^{-1}$ but provided forage yield of 4.9 $\mathrm{Mg} \mathrm{ha}^{-1}$. Annualized net returns in annual forage-durum systems were $\$ 127 \mathrm{ha}^{-1}, \$ 77$ and $\$ 34 \mathrm{ha}^{-1}$ greater than for fallowdurum and alfalfa, respectively. Replacing summer fallow with annual forages reduced durum yield but improved profitability.
\end{abstract}

$\mathrm{C}$ ROP DIVERSIFICATION, reduced fallow periods, and limited inputs are being promoted in the Great Plains to improve economic and environmental sustainability in dryland cropping systems (Peterson et al., 1993). In Montana, more than 1.59 million ha or $36 \%$ of the dryland acreage for annual crop production was in summer fallow in 2003 (NASS, 2010). Producers are encouraged to diversify crops away from monocultures, primarily wheat (T. aestivum L.), to reduce the area of land under fallow, and to reduce farm inputs, especially those that have negative impacts on economic and environmental sustainability (Matson et al., 1997; Struick and Bonciarelli, 1997; Gregory et al., 2002).

Water typically is the primary limiting factor for growing crops in durum-based cropping systems in the semiarid northern Great Plains (NGP). Conventional summer fallow usually increases both soil water storage and $\mathrm{NO}_{3}-\mathrm{N}$ concentration for subsequent crop use. Summer fallow, however, is inefficient for precipitation

A.W. Lenssen and U. M. Sainju, USDA-ARS, Northern Plains Agric. Res. Laboratory, Sidney, MT 59270; S.D. Cash, P.G. Hatfield, H.B. Goosey, G.D. Johnson, Dep. Animal and Range Sciences, Montana State Univ., Bozeman, MT 59717; W.R. Grey, Dep. Plant Science and Plant Pathology, Montana State Univ., Bozeman, MT 59717; D.A. Griffith, Dep. Agricultural Economics and Economics, Montana State Univ., Bozeman, MT 59717; S.L. Blodgett, Dep. Plant Science, South Dakota State Univ., Brookings, SD 57006. Received 25 Feb. 2010. ${ }^{*}$ Corresponding author (andy.lenssen@ars.usda.gov).

Published in Agron. J. 102:1261-1268 (2010)

Published online 2 June 2010

doi:10.2134/agronj2010.0078

Copyright $\odot 2010$ by the American Society of Agronomy, 5585 Guilford Road, Madison, WI 53711. All rights reserved. No part of this periodical may be reproduced or transmitted in any form or by any means, electronic or mechanical, including photocopying, recording, or any information storage and retrieval system, without permission in writing from the publisher. storage, averaging only $25 \%$ efficiency in tilled systems (Farahani et al., 1998). Intensification of crop production by reducing summer fallow provides more efficient utilization of water in the semiarid central Great Plains (Farahani et al., 1998).

Available $\mathrm{N}$ is the second most limiting factor for dryland crop production in semiarid agroecosystems (O'Leary and Connor, 1997). Soil $\mathrm{NO}_{3}-\mathrm{N}$ availability is usually related to cereal yields. Increased $\mathrm{NO}_{3}-\mathrm{N}$ content can also contaminate surface and groundwater due to $\mathrm{N}$ leaching and surface runoff. For decreasing fertilizer $\mathrm{N}$ applications and improving $\mathrm{N}$ utilization, producers are encouraged to diversify away from cereal monocultures, primarily spring wheat and durum, to improve crop $\mathrm{N}$ uptake and reduce residual soil $\mathrm{N}$ and $\mathrm{N}$ leaching. Additionally, purchasing fertilizer $\mathrm{N}$ is a significant expense for producers.

Improved nutrient-use efficiency, particularly $\mathrm{N}$, is an important goal in cropping systems (Karlen et al., 1994; Raun and Johnson, 1999). Huggins and Pan (2003) showed determination of key indicators of nitrogen use efficiency (NUE) in cereal-based agroecosystems enabled broad assessment of agronomic management and environmental factors related to $\mathrm{N}$ use. Key indicators of NUE include $\mathrm{N}$ in grain and $\mathrm{N}$ aboveground biomass, $\mathrm{N}$ harvest index, and grain $\mathrm{N}$ accumulation efficiency.

Annual cereal forage crops are well adapted to semiarid NGP environments (Hedel and Helm, 1993; Carr et al., 1998, 2004; Lenssen, 2008). Replacing summer fallow with annual forages may be an effective cropping system to improve soil quality and producers' returns. Due to the short growing seasons, annual forages may use less soil water than do grain and oilseed crops (Aase

Abbreviations: ADF, acid detergent fiber; CP, crude protein; DM, dry matter; $\mathrm{HI}$, harvest index; NDF, neutral detergent fiber; NGP, northern Great Plains; NRI, nitrogen recovery index; NUE, nitrogen use efficiency; $\mathrm{POSTH}_{2} \mathrm{O}$, postharvest soil water content; $\mathrm{PREH}_{2} \mathrm{O}$, preplant soil water content; WU, water use; WUE, water use efficiency. 
Table I. Monthly and annual precipitation from 2002-2006 at the experimental site, II km south of Froid, MT.

\begin{tabular}{|c|c|c|c|c|c|c|c|c|c|c|c|c|}
\hline \multirow[b]{2}{*}{ Month } & \multicolumn{6}{|c|}{ Precipitation } & \multicolumn{6}{|c|}{ Temperature } \\
\hline & 2002 & 2003 & 2004 & 2005 & 2006 & I05-yr avg. $\dagger$ & 2002 & 2003 & 2004 & 2005 & 2006 & I 05-yr avg. $\dagger$ \\
\hline & \multicolumn{6}{|c|}{$\mathrm{mm}$} & \multicolumn{6}{|c|}{${ }^{\circ} \mathrm{C}$} \\
\hline April & 14 & 26 & 18 & 6 & 91 & 24 & 3 & 8 & 6 & 8 & 9 & 6 \\
\hline May & 17 & 68 & 73 & 96 & 40 & 50 & 9 & 12 & 10 & 10 & 13 & 13 \\
\hline June & 87 & 73 & 33 & 170 & 50 & 77 & 17 & 16 & 14 & 17 & 18 & 17 \\
\hline July & 7I & 37 & 85 & 38 & 4 & 54 & 22 & 22 & 19 & 21 & 24 & 21 \\
\hline August & 46 & 50 & 62 & 46 & 28 & 36 & 18 & 23 & 16 & 19 & 21 & 20 \\
\hline September & 25 & 22 & 22 & 2 & 68 & 33 & 14 & 13 & 14 & 14 & 13 & 14 \\
\hline Total & 291 & 347 & 332 & 423 & 321 & 340 & & & & & & \\
\hline
\end{tabular}

† Long-term averages from National Oceanic and Atmospheric Administration (www.nws.noaa.gov) for Culbertson, MT, located II km south of the research site.

and Pikul, 2000; Pikul et al., 2004). Forages from cereal crops provide quality forage for overwintering beef cattle (Bos taurus).

The successful inclusion of perennial forage crops in grainbased cropping systems has been well documented in the NGP. In a recent review, Entz et al. (2002) summarized research from the Canadian prairie and United States, showing rotational benefits of perennial forages for $\mathrm{N}$ availability and pest management by including them in cereal-based rotations. However, the resultant yield by including annual cereal forages into cereal-based rotations is not available.

We developed a dryland cropping system with input from producers in the selection of crop species, cropping sequences, and management. Our objectives were to: (i) determine forage yield and quality, and water and $\mathrm{N}$ use of annual forages in rotation with durum and (ii) yield, quality, and water and $\mathrm{N}$ use of durum in rotation with annual forages and summer fallow.

\section{MATERIALS AND METHODS}

The experimental site was located at the USDA Conservation District Farm, $11 \mathrm{~km}$ north of Culbertson, Montana $\left(48^{\circ} 16^{\prime} \mathrm{N}, 104^{\circ} 30^{\prime} \mathrm{W}\right.$; altitude $\left.660 \mathrm{~m}\right)$. The 8.2-ha field site was located in an area mapped as Williams loam (fine-loamy, mixed, superactive, frigid Typic Argiustolls, 2-8\% slopes) derived from glacial till. Soil sampling in October 2001 revealed average organic matter concentration as $11 \mathrm{~g} \mathrm{~kg}^{-1}$, Olsen P $8.3 \mathrm{mg} \mathrm{kg}^{-1}$,

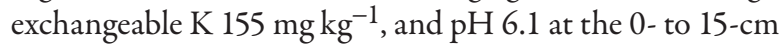
depth. Mean annual precipitation at the site is $340 \mathrm{~mm}, 80 \%$ of which occurs from April through September (Table 1). Previous cropping history was spring wheat or durum in rotation with summer fallow, except for 2000, when lentil (Lens culinaris Medik.) was planted and incorporated as a green manure.

The experiment consisted of four crop rotations and tetraploid alfalfa 'Shaw'. Crop rotations included spring durum 'Mountrail' in rotation with summer fallow and three annual forage crops, which were forage barley 'Haybet', forage barley interseeded with Austrian winter pea (variety not stated), and foxtail millet 'Golden German'. The experimental design was a randomized complete block with three replications. Individual plot size was 21.3 by $61 \mathrm{~m}$. Starting in 2002, each phase of the crop rotation was present in each replication and every year. Forage crops planted in 2002 followed durum, allowing comparison of forage yields from 2002 to 2006. Rotational phases preceding durum, annual forages and summer fallow, were not in place until 2002, so durum yields are provided from 2003 to 2006.

Available P levels from soil samples taken in 2001 were low, so $336 \mathrm{~kg} \mathrm{ha}^{-1}$ of monoammonium phosphate was broadcast to all plots, except alfalfa, which received $644 \mathrm{~kg} \mathrm{ha}^{-1}$ before planting in 2002. Nitrogen fertilizer rates were based on a durum yield goal of $2350 \mathrm{~kg} \mathrm{ha}^{-1}$ with $135 \mathrm{~g} \mathrm{~kg}^{-1}$ protein, resulting in $118 \mathrm{~kg} \mathrm{~N} \mathrm{ha}^{-1}$ (Jacobsen et al., 2003). Fertilizer $\mathrm{N}$ requirement for annual forages was $100 \mathrm{~kg} \mathrm{~N} \mathrm{ha}^{-1}$, with residual $\mathrm{NO}_{3}-\mathrm{N}$ level from the 0 - to 60-cm depth (determined in mid-October) subtracted for determination of fertilizer $\mathrm{N}$ rate. Following Montana State University recommendations (Jacobsen et al., 2003), annual applications of monoammonium phosphate and potash were provided to all annual crops at 56 and $48 \mathrm{~kg} \mathrm{ha}^{-1}$, respectively. For 2002 and 2003, fertilizers were spread before preplant tillage using a granular applicator equipped with an air delivery system. From 2004 to 2006, fertilizers were banded at planting with bands located about $5 \mathrm{~cm}$ below and to the side of each seed row. In 2002, preplant tillage was done with a tandem disc. From 2003 to 2006, preplant tillage was done by a single pass with a field cultivator equipped with C-shanks and 45-cm wide sweeps and coil-tooth spring harrows with $60 \mathrm{~cm}$ bars. Tillage depth, 7 to $8 \mathrm{~cm}$, was controlled by stabilizer wheels on the field cultivator frame.

Seeding dates were typical for the region. Durum, barley, and barley-pea were planted in mid- to late April each year, except 2002, when planting was done 28 May. Seeding rates were 900,000 seed acre $^{-1}$ for durum and barley; pea was planted at 400,000 seed acre ${ }^{-1}$. Foxtail millet was planted at $22.4 \mathrm{~kg} \mathrm{ha}^{-1}$ between late May and early June each year. Alfalfa was seeded once on 28 May 2002 at $9.0 \mathrm{~kg} \mathrm{ha}^{-1}$ at 1 -cm depth. In 2002 and 2003, planting was done with a 2.1-m wide drill equipped with double-disk openers on $20 \mathrm{~cm}$ centers. From 2004-2006, planting was done with a 3.05-m wide custom built drill equipped with double-shoot Barton ${ }^{3}$ openers for single-pass seeding and fertilization. Seeding depth varied by crop and year according to soil water content. Austrian winter pea was planted at 7-cm depth in 2002 and 2003 before overseeding with barley. Durum was planted at 3.8- to 5-cm depth. In 2004-2006, Austrian winter pea and barley were seeded at 3.8 - to 5 -cm depth in a single pass. Foxtail millet was seeded at 1.9- to 2.4-cm depth. Alfalfa was planted only in 2002.

A tank-mixed application of $0.68 \mathrm{~kg} \mathrm{ha}^{-1}$ of formulated bromoxynil (3,5-dibromo-4-hydroxybenzonitrile) and MCPA ester (2-methy-4-chlorophenoxyacetic acid) (0.92:1) and $0.09 \mathrm{~kg}$ a.i. ha $^{-1}$ fenoxaprop-P-ethyl (\{+\}-ethyl 2-\{4-[(6-chloro2-benzoxazolyl)oxy] phenoxy\}propanoate) (in $38 \mathrm{~L} \mathrm{ha}^{-1}$ water was applied before canopy closure for control of broadleaf and grass weeds each year in durum plots. Forage crops, including alfalfa, did not receive any in-crop herbicide applications. Summer fallow plots received tank-mixed applications of glyphosate [N-(phosphonomethyl)glycine] and dicamba (3,6-dichloro-o-anisic 
acid) $\left[3.36 \mathrm{~kg}\right.$ and $0.56 \mathrm{~kg}$ a.i. ha ${ }^{-1}$, respectively, in $37.8 \mathrm{~L} \mathrm{ha}^{-1}$ water as required until 1 September, after which a single application of glyphosate ( $3.36 \mathrm{~kg}$ a.i. ha ${ }^{-1}$ in $37.8 \mathrm{~L} \mathrm{ha}^{-1}$ water)] for weed management, if necessary. Postharvest weed management was done on durum stubble with glyphosate $\left(3.36 \mathrm{~kg}\right.$ a.i. $\mathrm{ha}^{-1}$ in $37.8 \mathrm{~L} \mathrm{ha}^{-1}$ water) and on annual hay crop stubble with glyphosate and dicamba (3.36 kg a.i. ha ${ }^{-1}$ and $0.56 \mathrm{~kg}$ a.i. ha ${ }^{-1}$, respectively, in $37.8 \mathrm{~L} \mathrm{ha}^{-1}$ water). Postharvest herbicide application for weed control was not done on durum plots in 2003.

Stand densities of annual crops were determined by counting all plants in 4-m length of row in each plot at the one- to two-leaf stage. Stand density of alfalfa was determined only in 2004. One day before harvest, aboveground biomass from hay and durum plots was determined by clipping two $0.5-\mathrm{m}^{2}$ areas. Samples were oven-dried at $55^{\circ} \mathrm{C}$, and weighed to determine aboveground biomass. Sampling was done at least $2 \mathrm{~m}$ away from plot boundaries to preclude sampling potential edge effects. Annual forages were harvested once per growing season. Alfalfa was harvested once per season in 2002 and 2006, but two harvests were taken per year from 2003-2005. Grain yield was determined with a selfpropelled plot combine equipped with a $1.5 \mathrm{~m}$ header by cutting a 25- to 59-m length, depending on yield and year. Yield samples were dried, cleaned with combinations of sieves and wind, and weighed. All grain and biomass data are presented as $100 \%$ dry matter (DM). Harvest index (HI) was calculated as:

$$
\mathrm{HI}=\mathrm{GY} / \mathrm{CB}
$$

where GY is grain yield $\left(\mathrm{kg} \mathrm{ha}^{-1}\right)$ and CB is crop biomass ( $\left.\mathrm{kg} \mathrm{ha}^{-1}\right)$ (Cassman et al., 1992).

Grain $\mathrm{N}$ concentration was determined with near infrared spectroscopy. Durum kernel weights were determined by machine counting three 1000 kernel samples and weighing samples. Soil water content was determined gravimetrically from soil samples taken before planting and shortly after harvest with a hydraulic probe. Sampling depths were 0 to 15,15 to 30,30 to 60, 60 to 90,90 to 120 , and 120 to $150 \mathrm{~cm}$. Water budgets were determined by calculating volumetric water from gravimetric water. Water use (WU in millimeters) was calculated as:

$$
\mathrm{WU}=\mathrm{PREH}_{2} \mathrm{O}-\mathrm{POSTH}_{2} \mathrm{O}+\text { PRECIP }
$$

where $\mathrm{PREH}_{2} \mathrm{O}$ is the preplant soil water content $(\mathrm{mm}$, $0-150 \mathrm{~cm}), \mathrm{POSTH}_{2} \mathrm{O}$ is the postharvest soil water content $(\mathrm{mm}$, $0-150 \mathrm{~cm}$ ), and PRECIP is precipitation between preplant and postharvest soil sampling (Farahani et al., 1998). Water use efficiency (WUE in $\mathrm{kg} \mathrm{ha}^{-1} \mathrm{~mm}^{-1}$ ) for forage crops was calculated as:

$$
\mathrm{WUE}_{\text {forage }}=\mathrm{FB} / \mathrm{WU}
$$

where $\mathrm{FB}$ is forage aboveground biomass $\left(\mathrm{kg} \mathrm{ha}^{-1}\right)$ and WU $(\mathrm{mm})$ is water use (Eq. [2]) (Farahani et al., 1998). The WUE $\left(\mathrm{kg} \mathrm{ha}^{-1} \mathrm{~mm}^{-1}\right)$ for durum grain was calculated as:

$$
\mathrm{WUE}_{\text {grain }}=\mathrm{GY} / \mathrm{WU}
$$

where GY is grain yield $\left(\mathrm{kg} \mathrm{ha}^{-1}\right)$ and WU $(\mathrm{mm})$ is water use (Eq. [2]) (Farahani et al., 1998). Surface water runoff was not evident during the course of the study and it was assumed that neither overland flow nor leaching of water below the sampled $1.5 \mathrm{~m}$ soil profile occurred.

Nitrogen recovery index for forage crops was calculated as:

$$
\mathrm{NRI}=(\mathrm{FB} \times \mathrm{N}) /\left(\mathrm{N}_{\text {res }}+\mathrm{N}_{\text {fert }}\right)
$$

where $\mathrm{FB}$ is forage biomass $\left(\mathrm{kg} \mathrm{ha}^{-1}\right), \mathrm{N}$ is nitrogen concentration in forage biomass $\left(\mathrm{kg}^{-1} \mathrm{~N} \mathrm{ha}^{-1}\right), \mathrm{N}_{\text {res }}$ is preplant residual $\mathrm{NO}_{3}{ }^{-}-\mathrm{N}\left(\mathrm{kg} \mathrm{N} \mathrm{ha}^{-1}, 0-60 \mathrm{~cm}\right)$, and $\mathrm{N}_{\text {fert }}$ is fertilizer nitrogen applied $\left(\mathrm{kg} \mathrm{N} \mathrm{ha}^{-1}\right)$ (Huggins and Pan, 2003). The NRI for grain was calculated as:

$$
\mathrm{NRI}_{\text {grain }}=\left(\mathrm{GY} \times \mathrm{N}_{\text {grain }}\right) /\left(\mathrm{N}_{\text {res }}+\mathrm{N}_{\text {fert }}\right)
$$

where GY is grain yield $\left(\mathrm{kg} \mathrm{ha}^{-1}\right), \mathrm{N}_{\text {grain }}$ is grain $\mathrm{N}$ concentration in grain $\left(\mathrm{g} \mathrm{kg}^{-1}\right), \mathrm{N}_{\text {res }}$ is preplant residual $\mathrm{NO}_{3}{ }^{-} \mathrm{N}\left(\mathrm{kg} \mathrm{N} \mathrm{ha}^{-1}\right.$, $0-60 \mathrm{~cm}$ ), and $\mathrm{N}_{\text {fert }}$ is fertilizer $\mathrm{N}$ applied $\left(\mathrm{kg} \mathrm{N} \mathrm{ha}^{-1}\right.$ ) (Huggins and Pan, 2003).

Economic returns to land and management for durum were done with the North Dakota State University Farm Management Planning Guides for 2002-2006 for recrop and fallow systems in the northwest North Dakota region. Production costs for alfalfa were developed using common dryland practices and the Haying Systems Cost Working Sheet from Montana State University Cooperative Extension Service. Production costs for annual forages were developed using the NDSU guides and MSU working sheet for planting and land, and harvest costs, respectively. Gross returns for durum, alfalfa, and other hay, were calculated based on 4-yr averages for Montana (NASS, 2010), excluding government payments, using annualized production values from this study.

Data were analyzed with PC-SAS using the MIXED procedure (SAS Institute, 2003) for a split-plot analysis with entry (or rotation) as whole-plot factor, year as subplot factor, and their interaction considered fixed effects. Replicate and replicate $\times$ entry (or rotation) were considered random effects. Arcsine-square root transformations were done for percentage data before analyses. Mean separations were done by least square means test. Differences among treatments are reported at the $5 \%$ level of significance. Following Pearson correlation analyses, selected regression analyses were computed with the PROC REG routine in PC-SAS to determine the relationships between crop production and water use.

\section{RESULTS AND DISCUSSION Climate}

Precipitation and average temperature over the course of the experiment were variable, typical of NGP environments. The 2002, 2003, and 2004 seasons had near-normal precipitation (Table 1). Conversely, precipitation in May and June 2005 was well above the long-term average while that of May through August 2006 was well below the long-term average. Air temperature was above the long-term average in July 2006, and when combined with a total of $4 \mathrm{~mm}$ precipitation during July, durum, millet, and alfalfa were exposed to substantial drought and heat stress.

\section{Forage Crops \\ Forage Yield and Water Relations}

Forage yield, preplant soil water, WU, and WUE varied for the forage crop $\times$ year interaction (Table 2 ). Alfalfa had lowest yield in 2002, the year of establishment, but in subsequent years, its yield was among the highest of all other forages (Table 3). Stand density of alfalfa averaged $86 \mathrm{~m}^{2}$ in 2002, but stands were not determined in subsequent years. Yields of barley and barley-pea were similar for all $5 \mathrm{yr}$, similar to results for annual cereal and cereallegume intercrops in other trials conducted in semiarid regions 
Table 2. Analysis of variance for forage yield, water use, preplant soil water content ( $\mathrm{PREH} \mathrm{H}_{2} \mathrm{O}, 0$ - to I50-cm depth), postharvest soil water content $\left(P O S T H_{2} O, 0\right.$ - to $150-\mathrm{cm}$ depth), water-use efficiency (WUE), crude protein (CP), neutral detergent fiber (NDF), and acid detergent fiber (ADF) following durum.

\begin{tabular}{|c|c|c|c|c|c|c|c|c|}
\hline Source of variation & Forage yield & Water use & $\mathrm{PREH}_{2} \mathrm{O}$ & $\mathrm{POSTH}_{2} \mathrm{O}$ & WUE & $\mathbf{C P}$ & NDF & ADF \\
\hline Forage crop & $\mathrm{Mg} \mathrm{ha}^{-1}$ & 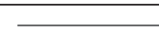 & $\mathrm{mm}$ & 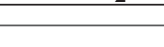 & $\mathrm{kg} \mathrm{ha}^{-1} \mathrm{~mm}^{-1}$ & 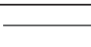 & $\mathrm{g} \mathrm{kg}^{-1}$ & 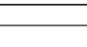 \\
\hline Barley & $5.0 \mathrm{bt}$ & $215 \mathrm{~b}$ & $166 \mathrm{a}$ & $126 \mathrm{a}$ & 23.1 & $118 \mathrm{c}$ & $589 \mathrm{~b}$ & 315 \\
\hline Barley + pea & $5.2 \mathrm{ab}$ & $221 \mathrm{ab}$ & $167 \mathrm{a}$ & $120 \mathrm{a}$ & 23.2 & $133 \mathrm{~b}$ & $561 \mathrm{c}$ & 311 \\
\hline Millet & $4.5 \mathrm{c}$ & $187 \mathrm{c}$ & $17 \mid$ a & $134 \mathrm{a}$ & 24.7 & $108 d$ & $626 \mathrm{a}$ & 320 \\
\hline Alfalfa & $5.5 \mathrm{a}$ & $237 \mathrm{a}$ & $116 \mathrm{~b}$ & $93 \mathrm{~b}$ & 23.2 & $188 \mathrm{a}$ & $432 d$ & 313 \\
\hline \multicolumn{9}{|l|}{ Year } \\
\hline 2002 & $3.7 \mathrm{c}$ & $168 d$ & $127 c$ & 119 & 21.8 & $123 \mathrm{~b}$ & $584 \mathrm{a}$ & $304 b$ \\
\hline 2003 & $5.6 \mathrm{~b}$ & $245 b$ & $178 \mathrm{a}$ & 127 & 23.9 & $124 \mathrm{~b}$ & $575 \mathrm{a}$ & $339 a$ \\
\hline 2004 & $5.5 \mathrm{~b}$ & $219 c$ & $155 \mathrm{~b}$ & 123 & 25.4 & $144 \mathrm{a}$ & $537 \mathrm{~b}$ & $339 a$ \\
\hline 2005 & $6.6 \mathrm{a}$ & 292 a & $134 c$ & 110 & 22.8 & $150 \mathrm{a}$ & $546 \mathrm{~b}$ & $325 \mathrm{a}$ \\
\hline 2006 & $3.8 \mathrm{c}$ & $152 d$ & $180 \mathrm{a}$ & 113 & 26.8 & $14 \mid \mathrm{c}$ & $517 c$ & $264 c$ \\
\hline Significance & \multicolumn{8}{|c|}{$\underline{P \text { value }}$} \\
\hline Rotation (R) & $* * *$ & $* * *$ & $* * *$ & $* * *$ & nsł & $* * *$ & $* * *$ & ns \\
\hline Year (Y) & $* * *$ & $* * *$ & $* *$ & ns & ns & $* * *$ & $* *$ & $* *$ \\
\hline$R \times Y$ & $* * *$ & $* * *$ & $* *$ & ns & $* * *$ & $* * *$ & $* * *$ & $*$ \\
\hline
\end{tabular}

* Significant at $P \leq 0.05$.

** Significant $P \leq 0.01$.

$* * *$ Significant $P \leq 0.001$.

$\dagger$ Means followed by different lowercase letter within a column are significantly different at $P \leq 0.05$.

$\ddagger$ Not significant.

(Droushiotis, 1984; Carr et al., 2004). The contribution of pea in barley-pea biomass ranged from 6 to $23 \%$, despite planting similar pea/barley seeding rates (results not presented). Droushiotis (1989) also found a low percentage of pea in binary mixtures with cereal forages, primarily due to the high level of cereal competitiveness. Foxtail millet, the only warm-season forage, produced lower yield than other forages in 3 of $5 \mathrm{yr}$, perhaps due to inadequate precipitation during July and August most years (Table 1).

Table 3. Yield, preplant soil water content $(0-$ to $150-\mathrm{cm}$ depth), water use, and water use efficiency of forages following durum from 2002 to 2006.

\begin{tabular}{|c|c|c|c|c|c|}
\hline Forage crop & 2002 & 2003 & 2004 & 2005 & 2006 \\
\hline & \multicolumn{5}{|c|}{ Forage yield, $\mathrm{Mg} \mathrm{ha}^{-1}$} \\
\hline Barley & 4.3 a† & $5.1 \mathrm{~b}$ & $6.1 \mathrm{ab}$ & $6.1 \mathrm{bc}$ & $3.4 \mathrm{bc}$ \\
\hline Barley + pea & $4.3 \mathrm{a}$ & $5.5 \mathrm{ab}$ & $5.5 \mathrm{~b}$ & $6.7 \mathrm{~b}$ & $3.3 \mathrm{~b}$ \\
\hline Foxtail millet & $4.3 \mathrm{a}$ & $5.7 \mathrm{ab}$ & $4.3 \mathrm{c}$ & $5.2 \mathrm{c}$ & $2.8 \mathrm{c}$ \\
\hline \multirow[t]{2}{*}{ Alfalfa } & $1.7 \mathrm{~b}$ & $6.2 \mathrm{a}$ & $6.3 \mathrm{a}$ & $8.3 \mathrm{a}$ & $5.1 \mathrm{a}$ \\
\hline & \multicolumn{5}{|c|}{ Preplant soil water, $\mathrm{mm}$} \\
\hline Barley & 134 & 197 & $163 \mathrm{a}$ & $136 \mathrm{~b}$ & $201 \mathrm{a}$ \\
\hline Barley + pea & $|3|$ & 177 & $178 \mathrm{a}$ & $146 \mathrm{~b}$ & $200 \mathrm{a}$ \\
\hline Foxtail millet & 124 & 168 & $184 \mathrm{a}$ & $180 \mathrm{a}$ & 201 a \\
\hline \multirow[t]{2}{*}{ Alfalfa } & 117 & 172 & $96 \mathrm{~b}$ & $76 c$ & $121 \mathrm{~b}$ \\
\hline & \multicolumn{5}{|c|}{ Water use, $\mathrm{mm}$} \\
\hline Barley & 165 & $236 \mathrm{~b}$ & $219 a$ & $267 \mathrm{~b}$ & 186 a \\
\hline Barley + pea & 165 & $209 \mathrm{bc}$ & $250 \mathrm{a}$ & $314 a$ & $170 \mathrm{ab}$ \\
\hline Foxtail millet & 166 & $195 c$ & $180 \mathrm{~b}$ & $228 \mathrm{~b}$ & $114 \mathrm{c}$ \\
\hline \multirow[t]{2}{*}{ Alfalfa } & 174 & 339 a & $232 \mathrm{a}$ & $299 \mathrm{ab}$ & $142 \mathrm{bc}$ \\
\hline & \multicolumn{5}{|c|}{ Water use efficiency, $\mathrm{kg} \mathrm{ha}^{-1} \mathrm{~mm}^{-1}$} \\
\hline Barley & $26.1 \mathrm{a}$ & $21.8 \mathrm{bc}$ & 28.1 & $23.7 \mathrm{ab}$ & $18.0 \mathrm{c}$ \\
\hline Barley + pea & 26.1 a & $26.3 \mathrm{ab}$ & 22.5 & $21.5 \mathrm{ab}$ & $22.2 \mathrm{bc}$ \\
\hline Foxtail millet & $26.2 \mathrm{a}$ & $29.2 \mathrm{a}$ & 23.6 & $18.6 \mathrm{~b}$ & $25.7 \mathrm{~b}$ \\
\hline Alfalfa & $10.0 \mathrm{~b}$ & $18.1 \mathrm{c}$ & 27.3 & $27.9 \mathrm{a}$ & $37.1 \mathrm{a}$ \\
\hline
\end{tabular}

$\dagger$ Means followed by different lowercase letter within a column are significantly different at $P \leq 0.05$.
In the initial $2 \mathrm{yr}$ of the study, preplant soil water content was similar among annual forages and alfalfa, but in subsequent years, water content was lower in alfalfa than in other forages, probably due to longer growth period and greater rooting depth (Table 3). Postharvest soil water content varied among forages, with lower water content in alfalfa than in other forages (Table 2). Water use was different among forages (Table 3). Alfalfa had highest water use in the second year of the study, but by the fifth year, it had lower water use compared to barley due to greater water extraction in previous years and lack of profile recharge during the previous winter. Foxtail millet had lower water use compared to other annual forages and alfalfa in 3 out of $5 \mathrm{yr}$.

Water use efficiency for forages was not consistent among years, an expected result in semiarid environments with variable precipitation. The WUE for alfalfa was similar to that reported by Jefferson and Cutforth (2005) from nearby Swift Current, SK, except for our final year, 2006, when alfalfa had very high WUE. Jefferson and Cutforth (2005) sampled soil water to $2.7 \mathrm{~m}$ depth while we sampled only to $1.5 \mathrm{~m}$ depth, perhaps underestimating total soil water depletion. Dardanelli et al. (1997) previously documented water uptake by alfalfa from depths $>200 \mathrm{~cm}$, deeper than our maximum sampling depth.

Barley-pea intercrops were not different from monocrop barley for forage yield, preplant and postharvest soil water content, water use (except 2005), or WUE (Table 3). The relationship between water use and forage yield was nearly identical for barley and barley-pea, so these crops were combined for regression analysis. The $\mathrm{C}_{4}$ grasses typically have superior tolerance to drought stress than $\mathrm{C}_{3}$ grasses (Ehleringer and Monson, 1993), however, in this study water use-forage yield relationships were similar among annual forages (Fig. 1). Averaged across $5 \mathrm{yr}$, WUE of the three annual forages and alfalfa also were remarkably similar (Table 3 ). 


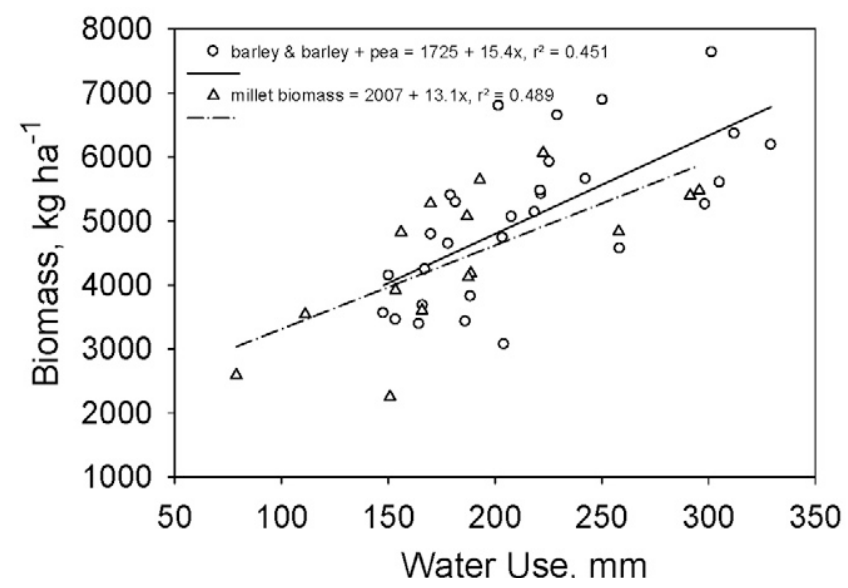

Fig. I. Relationship between annual forage biomass and water use from 2002 to 2006.

\section{Forage Quality}

Nutritive value of alfalfa, as estimated by CP and NDF, was superior to that of the annual forage (Table 4). The concentration of pea forage in total harvested biomass of the barley-pea intercrop ranged from a low of $60 \mathrm{~g} \mathrm{~kg}^{-1}$ in cooler, wetter 2005 to a maximum of $225 \mathrm{~g} \mathrm{~kg}^{-1}$ in drier, warmer 2006, with an overall mean across years of $136 \mathrm{~g} \mathrm{~kg}^{-1}$. The inclusion of pea with barley improved both CP and NDF over that of monocrop barley, as reported by several researchers (Carr et al., 2004; Strydhorst et al., 2008). In general, millet had the lowest CP and highest NDF of all forages. The NDF values indicate that alfalfa would have the highest intake by ruminant livestock, followed by barley-pea, barley, and millet. The ADF varied among forages in only 2 out of $5 \mathrm{yr}$, indicating that digestibility of these forages would be similar among entries. Cattle feeding trials have been conducted with cereal hay of similar forage quality as in the present study (Stamm et al., 2006; Todd et al., 2007). Barley, wheat, and oat (Avena sativa L.) hay were fed to
Table 4. Crude protein (CP), neutral detergent fiber (NDF), and acid detergent fiber (ADF) of forages following durum from 2002 to 2006.

\begin{tabular}{|c|c|c|c|c|c|}
\hline Forage & 2002 & 2003 & 2004 & 2005 & 2006 \\
\hline & \multicolumn{5}{|c|}{$\mathrm{CP}, \mathrm{g} \mathrm{kg}^{-1}$} \\
\hline Barley & $110 \mathrm{ct}$ & $117 c$ & $106 c$ & $130 \mathrm{c}$ & $127 \mathrm{c}$ \\
\hline Barley + pea & $134 \mathrm{~b}$ & $140 \mathrm{~b}$ & $118 \mathrm{bc}$ & $149 \mathrm{~b}$ & $153 \mathrm{~b}$ \\
\hline Foxtail millet & $86 d$ & $80 \mathrm{~d}$ & $129 \mathrm{~b}$ & $120 \mathrm{c}$ & $98 \mathrm{~d}$ \\
\hline \multirow[t]{2}{*}{ Alfalfa } & $162 \mathrm{a}$ & $160 \mathrm{a}$ & $225 \mathrm{a}$ & $202 \mathrm{a}$ & $188 \mathrm{a}$ \\
\hline & \multicolumn{5}{|c|}{ NDF, $\mathrm{g} \mathrm{kg}^{-1}$} \\
\hline Barley & $64 \mathrm{I} a$ & $599 \mathrm{~b}$ & $582 \mathrm{~b}$ & $586 \mathrm{ab}$ & $540 \mathrm{~b}$ \\
\hline Barley + pea & $617 \mathrm{~b}$ & $560 c$ & $534 c$ & $574 b$ & $518 b$ \\
\hline Foxtail millet & $627 \mathrm{ab}$ & $655 a$ & $642 \mathrm{a}$ & $601 \mathrm{a}$ & $607 a$ \\
\hline \multirow[t]{2}{*}{ Alfalfa } & 452 c & $486 \mathrm{~d}$ & $388 \mathrm{~d}$ & $432 c$ & $402 c$ \\
\hline & \multicolumn{5}{|c|}{ ADF, $\mathrm{g} \mathrm{kg}^{-1}$} \\
\hline Barley & 295 & $332 a b$ & $352 b$ & 337 & 259 \\
\hline Barley + pea & 315 & $319 b$ & $319 c$ & 336 & 263 \\
\hline Foxtail millet & 309 & $334 a b$ & $375 a$ & 308 & 275 \\
\hline Alfalfa & 298 & $367 a$ & $319 c$ & 326 & 262 \\
\hline
\end{tabular}

$\dagger$ Means followed by different lowercase letter within a column are significantly different at $P \leq 0.05$.

weaned steers in high roughage backgrounding diets. In both trials, the steers on high roughage diets had forage intake levels ranging from 2.2 to $2.6 \%$ of liveweight, and average daily gains ranging from 1.14 to $1.29 \mathrm{~kg} \mathrm{~d}^{-1}$. Based on the performance of cereal forages in growth rations, it appears that these forages are also suitable for winter maintenance diets for pregnant cattle and sheep (Ovis aries) (Cash et al., 2009).

\section{Forage and Soil Nitrogen}

Annual forages had similar levels of soil residual $\mathrm{N}$, fertilizer $\mathrm{N}$ requirement, and total available $\mathrm{N}$ (0- to 60-cm depth) across years (Table 5). Aboveground biomass $\mathrm{N}$ was greater in barleypea intercrop than in barley or millet. The NRI did not vary

Table 5. Soil residual $\mathbf{N}(0-$ to $60-\mathrm{cm}$ depth), $\mathbf{N}$ fertilizer requirement, total available $\mathbf{N}$, forage biomass $\mathbf{N}$, and nitrogen recovery index (NRI) for forages following durum averaged across years.

\begin{tabular}{|c|c|c|c|c|c|}
\hline & Residual N & Fertilizer $\mathbf{N}$ & Total available $\mathbf{N}$ & Biomass $\mathbf{N}$ & NRI \\
\hline Forage crop & 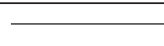 & 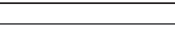 & & 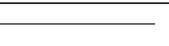 & \\
\hline Barley & 39 & 52 & 92 & $95 \mathrm{b \dagger}$ & 1.06 \\
\hline Barley + pea & 49 & 50 & 98 & $109 \mathrm{a}$ & 1.14 \\
\hline Foxtail millet & 41 & 49 & 91 & $81 \mathrm{c}$ & 0.92 \\
\hline Alfalfa $\ddagger$ & 26 & 11 & 36 & 166 & 9.10 \\
\hline \multicolumn{6}{|l|}{ Year } \\
\hline 2002 & $69 \mathrm{a}$ & 32 & 101 & $78 c$ & $0.8 \mathrm{I} \mathrm{bc}$ \\
\hline 2003 & $16 \mathrm{~b}$ & 81 & 97 & $97 \mathrm{~b}$ & $1.00 \mathrm{ab}$ \\
\hline 2004 & $28 \mathrm{~b}$ & 65 & 93 & $98 \mathrm{~b}$ & $1.07 \mathrm{a}$ \\
\hline 2005 & $32 \mathrm{~b}$ & 76 & 108 & $126 \mathrm{a}$ & $1.18 \mathrm{a}$ \\
\hline 2006 & $70 \mathrm{a}$ & 31 & 101 & $70 c$ & $0.76 c$ \\
\hline Significance & & & $\underline{P \text { value }}$ & & \\
\hline Rotation (R) & ns & & & $* * *$ & ns \\
\hline Year $(Y)$ & $*$ & & & $* * *$ & $*$ \\
\hline$R \times Y$ & ns & & & ns & $\mathrm{ns}$ \\
\hline
\end{tabular}

* Significant at $P \leq 0.05$.

$* * *$ Significant at $P \leq 0.001$.

$\dagger$ Means followed by different lowercase letter within a column are significantly different at $P \leq 0.05$.

$\ddagger$ Alfalfa not included in statistical analyses.

II Not significant. 
Table 6. Analysis of variance for durum grain and biomass yields, harvest index (HI), water use (WU), preplant soil water content $\left(P R E H_{2} \mathrm{O}, 0\right.$ - to $150-\mathrm{cm}$ depth), postharvest soil water content $\left(\mathrm{POSTH} \mathrm{H}_{2} \mathrm{O}, 0\right.$ - to 150 -cm depth), water-use efficiency (WUE, grain), and kernel weight following forages.

\begin{tabular}{|c|c|c|c|c|c|c|c|c|}
\hline Durum in rotation & Grain & Biomass & HI & $\mathrm{PREH}_{2} \mathbf{O}$ & $\mathrm{POSTH}_{2} \mathrm{O}$ & WU & WUE & Kernel weight \\
\hline & \multicolumn{2}{|c|}{$\longrightarrow \mathrm{kg} \mathrm{ha}^{-\mathrm{l}}$} & & 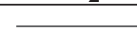 & $\mathrm{mm}$ & 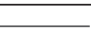 & $\mathrm{kg} \mathrm{ha}^{-1} \mathrm{~mm}^{-1}$ & mg kernel ${ }^{-1}$ \\
\hline Durum-fallow & 3211 at & 8037 a & 0.40 & $210 \mathrm{a}$ & 126 & $301 \mathrm{a}$ & 11.2 & $32.4 \mathrm{~b}$ \\
\hline Durum-barley & $2487 b$ & $6121 \mathrm{bc}$ & 0.43 & $\mathrm{I} 74 \mathrm{~b}$ & 133 & $260 \mathrm{~b}$ & 10.0 & $34.3 \mathrm{ab}$ \\
\hline Durum-barley + pea & $2508 b$ & $6467 b$ & 0.41 & $169 \mathrm{~b}$ & 130 & $257 b$ & 10.3 & $33.9 \mathrm{ab}$ \\
\hline Durum-foxtail millet & $2458 b$ & $5735 \mathrm{c}$ & 0.43 & $176 \mathrm{~b}$ & 135 & $259 \mathrm{~b}$ & 9.5 & $35.4 \mathrm{a}$ \\
\hline \multicolumn{9}{|l|}{ Year } \\
\hline 2003 & 3176 a & $5269 c$ & $0.61 \mathrm{a}$ & 181 & $112 \mathrm{c}$ & $229 c$ & $14.4 \mathrm{a}$ & $34.1 \mathrm{~b}$ \\
\hline 2004 & $3163 \mathrm{a}$ & $7346 b$ & $0.44 b$ & 183 & 129 bc & $307 \mathrm{~b}$ & $10.3 \mathrm{~b}$ & $45.1 \mathrm{a}$ \\
\hline 2005 & $305 \mathrm{I}$ a & 9309 a & $0.33 \mathrm{c}$ & 170 & $15 \mid \mathrm{a}$ & $374 \mathrm{a}$ & $8.2 \mathrm{c}$ & $32.7 b$ \\
\hline 2006 & 1274 b & $4443 \mathrm{~d}$ & $0.29 c$ & 195 & $132 a b$ & $166 d$ & $8.1 \mathrm{c}$ & $24.0 \mathrm{c}$ \\
\hline Significance & \multicolumn{8}{|c|}{$\underline{P \text { value }}$} \\
\hline Rotation (R) & $* * *$ & $* * *$ & nsł & $*$ & ns & $* * *$ & ns & $* *$ \\
\hline Year $(Y)$ & $* * *$ & $* * *$ & $* * *$ & ns & $*$ & $* * *$ & $* *$ & $* * *$ \\
\hline$R \times Y$ & $*$ & ns & ns & ns & ns & $*$ & ns & ns \\
\hline
\end{tabular}

* Significant at $P \leq 0.05$.

** Significant $P \leq 0.01$.

$* * *$ Significant $P \leq 0.001$

† Means followed by different lowercase letter within a column are significantly different at $P \leq 0.05$.

$\ddagger$ Not significant.

among annual forages. The mean value for NRI for the three annual forages (1.04) was superior to those typically reported for crops grown for grain, including wheat $(0.19-0.32$ in Huggins and Pan, 2003; 0.07-0.40 in Lenssen et al., 2007b). However, high NRI values for annual cereal forages are not unprecedented. Carr et al. (1998) provided preplant $\mathrm{NO}_{3}-\mathrm{N}$ content $(0-60 \mathrm{~cm})$ and forage $\mathrm{N}$ accumulation results whereby NRI could be calculated for barley and oat forages. The calculated NRI values averaged 1.51 and 2.71 over 2 yr for cereal crop forages following fallow and following continuous cropping, respectively, which were superior to those reported in this study. Clearly, annual cereal forages can have excellent NRI in the NGP.

Table 7. Durum grain yield, protein concentration, and water use following forages and summer fallow from 2003-2006.

\begin{tabular}{|c|c|c|c|c|}
\hline Durum in rotation & 2003 & 2004 & 2005 & 2006 \\
\hline & \multicolumn{4}{|c|}{ Grain yield, $\mathrm{kg} \mathrm{ha}^{-1}$} \\
\hline Durum-fallow & 3208 & 4225 a & $3712 \mathrm{a}$ & 1698 a \\
\hline Durum-barley & 3154 & 2779 bc & 2775 bc & $1240 \mathrm{ab}$ \\
\hline Durum-barley + pea & 3137 & $3157 \mathrm{~b}$ & $2519 c$ & $1218 \mathrm{ab}$ \\
\hline \multirow[t]{2}{*}{ Durum-foxtail millet } & 3204 & $2490 c$ & $3198 \mathrm{ab}$ & $940 \mathrm{~b}$ \\
\hline & \multicolumn{4}{|c|}{ Water use, $\mathrm{mm}$} \\
\hline Durum-fallow & 219 & 312 & 448 a & $225 \mathrm{a}$ \\
\hline Durum-barley & 226 & 298 & $332 b$ & $182 \mathrm{a}$ \\
\hline Durum-barley + pea & 238 & 316 & $349 \mathrm{~b}$ & $124 \mathrm{~b}$ \\
\hline \multirow[t]{2}{*}{ Durum-foxtail millet } & 232 & 302 & $367 b$ & $134 \mathrm{~b}$ \\
\hline & \multicolumn{4}{|c|}{ Grain protein, $\mathrm{g} \mathrm{kg}^{-1}$} \\
\hline Durum-fallow & $159 \mathrm{a}$ & 119 & 145 & 188 \\
\hline Durum-barley & $132 \mathrm{~b}$ & 124 & 155 & 178 \\
\hline Durum-barley + pea & $14 \mid \mathrm{b}$ & 130 & 161 & 185 \\
\hline Durum-foxtail millet & $127 \mathrm{~b}$ & 127 & 147 & $|8|$ \\
\hline
\end{tabular}

† Means followed by different lowercase letter within a column are significantly different at $P \leq 0.05$.

\section{Durum Yield and Water Relations}

The crop rotation $\times$ year interaction varied for durum grain yield and water use (Table 6). Grain yield was higher following fallow than following annual forages in 3 out of $4 \mathrm{yr}$ (Table 7). For 2 out of $4 \mathrm{yr}$, durum following fallow had higher WU than following annual forages, primarily due to greater $\mathrm{PREH}_{2} \mathrm{O}$. Postharvest soil water content for durum did not vary among crop rotations. The WUE for durum did not vary among rotations (Table 6). Crop biomass was greater for durum following fallow than for durum following annual forages, but $\mathrm{HI}$ did not vary among rotations.

Using results from all $4 \mathrm{yr}$, WU predicted durum aboveground biomass better than grain yield (Fig. 2). Drought and high temperature stress were shown to reduce photosynthesis, shoot and grain mass, and kernel weight of wheat (Shah and Paulsen, 2003), thereby decreasing yield. This semiarid region typically is water limited for cereal grain production, and durum and other cereals often are exposed to terminal drought before harvest. During our study, peak precipitation occurred in June for 2 of $4 \mathrm{yr}$ (2003 and 2005), and although June 2004 was drier than normal (Table 1), temperatures were relatively cool, precluding drought stress until late in July and August. Early and mid-season soil moisture contents likely were adequate for excellent aboveground biomass production, but drier and hotter conditions during fill possibly compromised ultimate grain carbohydrate content. In a related study, Lenssen et al. (2007a) reported that preplant soil water content, WU, and spring wheat yields and biomass were generally greater following summer fallow than following wheat, pulse, or oilseeds. Continuous cropping systems are more prone to suffer drought stress due to less preplant soil water following continuous cropping than following summer fallow (Lenssen et al., 2007a). Terminal drought frequently occurs in the NGP of Montana, and in part is responsible for the region's reputation for producing high quality durum. 
Table 8. Soil residual $\mathbf{N}$ at $\mathbf{0}$ - to $60-\mathrm{cm}$ depth, $\mathbf{N}$ fertilizer requirement, total available $\mathbf{N}$, durum grain and biomass $\mathbf{N}$, and nitrogen recovery index (NRI) for durum following forages and summer fallow averaged across years.

\begin{tabular}{|c|c|c|c|c|c|c|c|}
\hline \multirow[t]{2}{*}{ Durum in rotation } & \multirow[t]{2}{*}{ Residual N } & \multirow{2}{*}{$\frac{\text { Fertilizer } \mathbf{N}}{-\mathrm{kg} \mathrm{ha}^{-1}}$} & Total available $\mathbf{N}$ & \multicolumn{2}{|c|}{ Grain N } & Biomass $\mathbf{N}$ & \multirow[t]{2}{*}{ NRI } \\
\hline & & & - & $\mathrm{g} \mathrm{kg}^{-1}$ & 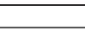 & $\mathrm{kg} \mathrm{ha}^{-1}$ & \\
\hline Durum-fallow & 62 at & 56 & 118 & $153 \mathrm{a}$ & $82 \mathrm{a}$ & $116 a$ & $0.68 \mathrm{a}$ \\
\hline Durum-barley & $4 \mid \mathrm{bc}$ & 76 & 118 & $147 \mathrm{~b}$ & $62 \mathrm{~b}$ & $100 \mathrm{~b}$ & $0.52 \mathrm{~b}$ \\
\hline Durum-barley + pea & $48 \mathrm{~b}$ & 70 & 117 & $154 \mathrm{a}$ & $65 \mathrm{~b}$ & $109 \mathrm{ab}$ & $0.56 \mathrm{~b}$ \\
\hline Durum-foxtail millet & $30 c$ & 84 & 114 & $145 \mathrm{~b}$ & $60 \mathrm{~b}$ & $88 c$ & $0.5 \mathrm{I} \mathrm{b}$ \\
\hline \multicolumn{8}{|l|}{ Year } \\
\hline 2003 & $34 \mathrm{~b}$ & 77 & 111 & 139 & 78 bc & $42 d$ & $0.71 \mathrm{a}$ \\
\hline 2004 & $44 \mathrm{~b}$ & 61 & 105 & 125 & $69 \mathrm{~b}$ & $118 \mathrm{~b}$ & $0.65 \mathrm{ab}$ \\
\hline 2005 & $36 \mathrm{~b}$ & 92 & 128 & 152 & $81 \mathrm{a}$ & 159 a & $0.63 \mathrm{~b}$ \\
\hline 2006 & $67 \mathrm{a}$ & 81 & 148 & $183 \mathrm{a}$ & $41 \mathrm{c}$ & $93 c$ & $0.28 \mathrm{c}$ \\
\hline Significance & \multicolumn{7}{|c|}{$\underline{P \text { value }}$} \\
\hline Rotation (R) & $* *$ & & & $*$ & $* * *$ & $*$ & $*$ \\
\hline Year $(Y)$ & $*$ & & & $* * *$ & $* * *$ & $* * *$ & $* * *$ \\
\hline$R \times Y$ & nsł & & & $*$ & ns & ns & ns \\
\hline
\end{tabular}

* Significant at $P \leq 0.05$.

** Significant $P \leq 0.01$.

*** Significant $P \leq 0.001$.

$\dagger$ Means followed by different lowercase letter within a column are significantly different at $P \leq 0.05$.

$\ddagger$ Not significant.

\section{Durum Nitrogen Relations}

The interaction of crop rotation $\times$ year varied for durum grain $\mathrm{N}$ concentration but crop rotation and year were significant for other parameters (Table 8). Durum following fallow in 2003 had higher $\mathrm{N}$ concentration than durum following annual forages. Durum following summer fallow had greater soil residual $\mathrm{N}$ compared to durum following annual forages, and consequently received less fertilizer $\mathrm{N}$ (Table 8). Durum following millet hay required higher fertilizer $\mathrm{N}$ rate than durum following fallow or barley-pea. The inclusion of pea with barley resulted in a nonsignificant slight increase in soil residual $\mathrm{N}$ and a consequent slight decrease in fertilizer $\mathrm{N}$ applied. However, grain N and NRI were similar for durum following barley and barley-pea. Inclusion of pea in rotation with barley did not reduce $\mathrm{N}$ fertilizer requirement for durum.

Nitrogen fertilizer is a costly input for NGP durum producers. Determining $\mathrm{N}$ fertilizer requirement for durum following a crop is not easy. In our study, durum following fallow had more grain $\mathrm{N}$ than durum following annual forages (Table 8). Similarly, durum following fallow had greater NRI than durum following annual forages. The lack of differences among crop rotations in durum grain protein concentration from 2004-2006 (Table 7) supports continued use of yield goals, $\mathrm{N}$ requirements, and late fall residual $\mathrm{NO}_{3}-\mathrm{N}\left(\mathrm{N}_{\text {res }}\right)$ to $60 \mathrm{~cm}$, as currently recommended in Montana (Jacobsen et al., 2003).

Annualized net returns were positive for durum-summer fallow, durum-annual forage, and alfalfa systems. Durum following summer fallow averaged $\$ 539 \mathrm{ha}^{-1}$ gross income. Following annual forages, durum averaged $\$ 409 \mathrm{ha}^{-1}$ gross income while annual forages added an additional $\$ 457 \mathrm{ha}^{-1}$. Conversely, summer fallow added $\$ 99 \mathrm{ha}^{-1}$ in costs but no direct income to the durum-summer fallow system, providing an annual net return to land and management of $\$ 50 \mathrm{ha}^{-1}$ for durum-summer fallow. Annualized net return to land and management for the durum-annual forage systems averaged $\$ 127 \mathrm{ha}^{-1}, \$ 77 \mathrm{ha}^{-1}$ greater than for durum-summer fallow.
Alfalfa hay averaged $\$ 84 \mathrm{ha}^{-1}$ net return to land and management over the $5 \mathrm{yr}, \$ 34 \mathrm{ha}^{-1}$ greater than for durum-summer fallow. Cereal hay was produced on more than 166,300 ha annually in Montana from 2002-2006, a small area compared to the $1.4 \mathrm{M}$ ha annually in summer fallow during that time period (NASS, unpublished data). Cereal hay production and market prices are no longer surveyed by NASS, however we assume that a large increase in land area devoted to production of annual or perennial hay crops that otherwise would be in summer fallow would decrease system net profitability.

\section{CONCLUSION}

Summer fallow is widely adopted in the NGP cropping systems, largely to stabilize wheat yields. In our study, regardless of the previous annual forage, durum following fallow had greater grain and biomass $\mathrm{N}$ and NRI, strongly indicating superior NUE. Preplant soil water content was higher following fallow than following annual forages, and durum responded to this

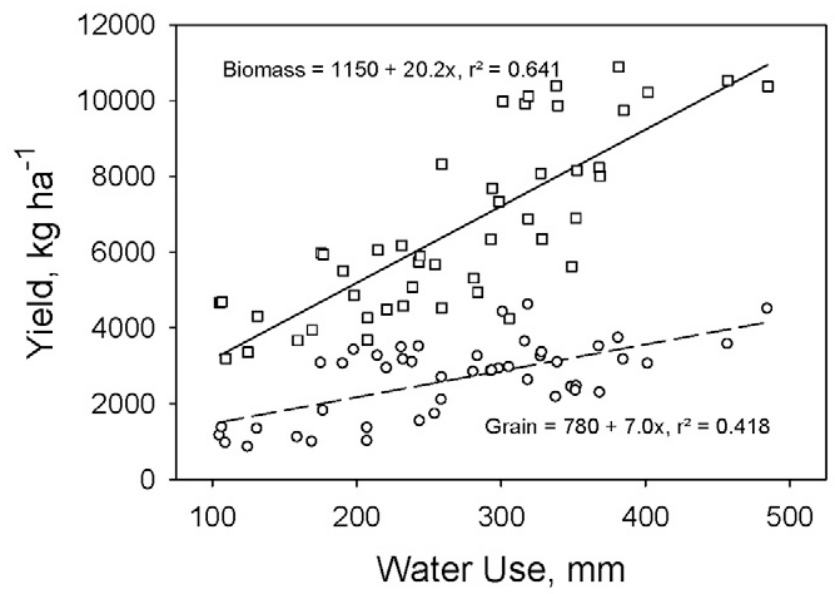

Fig. 2. Relationship between durum grain and biomass yields and water use from 2003 to 2006. 
additional water with higher yields. However, overall decrease in durum yield following annual forages was only $23 \%$ compared to durum following fallow. Annual forages produced average yield of $4.9 \mathrm{Mg} \mathrm{ha}^{-1}$, slightly lower than that of alfalfa. Water use was greater for alfalfa than for annual cereal forages. Although barley and barley-pea had higher WU than millet, preplant soil water content was similar for subsequent durum planting. Nutritive value of annual forages was lower than that of alfalfa, but was adequate for overwintering beef cattle. For annual forages, biomass $\mathrm{N}$ was greatest for barley-pea and lowest for foxtail millet. Overall, NRI and NUE of all annual forages and alfalfa were good. The cool season forages, barley and barley-pea, performed slightly better than foxtail millet, probably due to their better adaptation to the region's rainfall pattern. Replacing summer fallow with annual forages can be profitable for dryland producers in semiarid regions. This would not only provide durum for human consumption, but also supply high quality feed for ruminant livestock.

\section{ACKNOWLEDGMENTS}

The authors gratefully acknowledge technical support from Matt Connor, Mark Gaffri, Larry Hagenbuch, Jill Craig, Brady Paladichuk, and Nick Paritz. The Roosevelt and Sheridan County Conservation Districts kindly provided farmland on which to conduct this research. Partial financial support for this project was provided by USDA, CSREES Special Grants 'Sustainable Pest Management in Dryland Wheat' to A.W. Lenssen, G.D. Johnson, W.R. Gray, P.G. Hatfield, and S.L. Blodgett, Department of Entomology, Montana State University, Bozeman, MT.

\section{REFERENCES}

Aase, J.K., and J.L. Pikul, Jr. 2000. Water use in a modified summer fallow system on semiarid northern Great Plains. Agric. Water Manage. 43:345-357.

Carr, P.M., R.D. Horsley, and W.W. Poland. 2004. Barley, oat, and cereal-pea mixtures as dryland forages in the northern great plains. Agron. J. 96:677-684.

Carr, P.M., G.B. Martin, J.S. Caton, and W.W. Poland. 1998. Forage and nitrogen yield of barley-pea and oat-pea intercrops. Agron. J. 90:79-84.

Cash, S.D., P.L. Bruckner, D.M. Wichman, K.D. Kephart, J.E. Berg, R. Hybner, A.N. Hafla, L.M.M. Surber, D.L. Boss, G.R. Carlson, J.E. Eckhoff, R.N. Stougaard, G.D. Kushnak, and N.R. Riveland. 2009. Registration of 'Willow Creek' forage wheat. J. Plant Reg. 3:185-190.

Cassman, K.G., D.C. Bryant, A. Fulton, and L.F. Jackson. 1992. Nitrogen supply effects on partitioning of dry matter and grain of irrigated wheat. Crop Sci. 32:1251-1258.

Dardanelli, J.L., O.A. Bachmeier, R. Sereno, and R. Gil. 1997. Rooting depth and soil water extraction patterns of different crops in a silty loam Haplustoll. Field Crops Res. 54:29-38.

Droushiotis, D.N. 1984. The effect of variety and harvesting stage on forage production of barley in a low-rainfall environment. J. Agric. Sci. (Cambridge) 102:289-293.

Droushiotis, D.N. 1989. Mixtures of annual legumes and small-grained cereals for forage production under low rainfall.J. Agric. Sci. (Cambridge) 113:249-253.

Ehleringer, J.R., and R.K. Monson. 1993. Evolutionary and ecological aspects of photosynthetic pathway variation. Annu. Rev. Ecol. Syst. 24:411-439.
Entz, M.H., V.S. Baron, P.M. Carr, D.W. Meyer, S.R. Smith, Jr., and W.P. McCaughey. 2002. Potential of forages to diversity cropping systems in the northern Great Plains. Agron. J. 94:240-250.

Farahani, H.J., G.A. Peterson, and D.G. Westfall. 1998. Dryland cropping intensification: A fundamental solution to efficient use of precipitation. Adv. Agron. 64:197-223.

Gregory, P.J., J.S.I. Ingram, R. Andersson, R.A. Betts, V. Brovkin, T.N. Chase, P.R. Grace, A.J. Gray, N. Hamilton, T.B. Hardy, S.M. Howden, A. Jenkins, M. Meybeck, M. Olsson, I. Ortiz-Montasterio, C.A. Palm, T.W. Payn, M. Rummukainen, R.E. Schulze, M. Thiem, C. Valentin, and M.J. Wilkinson. 2002. Environmental consequences of alternative practices for intensifying crop production. Agric. Ecosyst. Environ. 88:279-290.

Hedel, P.E., and J.H. Helm. 1993. Forage potential of pulse-cereal mixtures in Central Alberta. Can. J. Plant Sci. 73:437-444.

Huggins, D.R., and W.L. Pan. 2003. Key indicators for assessing nitrogen use efficiency in cereal-based agroecosystems. J. Crop Prod. 8:157-185.

Jacobsen, J., G. Jackson, and C. Jones. 2003. Fertilizer guidelines for Montana crops. Coop. Ext. Publ. EB 161. Montana State Univ., Bozeman.

Jefferson, P.G., and H.W. Cutforth. 2005. Comparative forage yield, water use, and water use efficiency of alfalfa, crested wheatgrass and spring wheat in a semiarid climate in southern Saskatchewan. Can. J. Plant Sci. 85:877-888.

Karlen, D.L., G.E. Varvel, D.G. Bullock, and R.M. Cruse. 1994. Crop rotations for the 21st century. Adv. Agron. 53:1-45.

Lenssen, A.W. 2008. Preplant weed management and planting date influence yield, water use, and weed seed production in herbicide-free forage barley. Weed Technol. 22:486-492.

Lenssen, A.W., G.D. Johnson, and G.R. Carlson. 2007a. Cropping sequence and tillage system influences annual crop production and water use in semiarid Montana, USA. Field Crops Res. 100:32-43.

Lenssen, A.W., J. Waddell, G.D. Johnson, and G.R. Carlson. 2007b. Diversified cropping systems in semiarid Montana: Nitrogen use during drought. Soil Tillage Res. 94:362-375.

Matson, P.A., W.J. Parton, A.G. Power, and M.J. Swift. 1997. Agricultural intensification and ecosystem properties. Science (Washington, DC) 277:504-509.

NASS. 2010. Available at http://www.nass.usda.gov/Statistics_by_State/Montana/index.asp (accessed 27 Apr. 2010; verified 26 May 2010).

O’Leary, G.J., and D.J. Connor. 1997. Stubble retention and tillage in a semi-arid environment. 3 Response of wheat. Field Crops Res. 54:39-50.

Peterson, G.A., D.G. Westfall, and C. Cole. 1993. Agroecosystem approach to soil and crop management. Soil Sci. Soc. Am. J. 57:1354-1360.

Pikul, J.L., Jr., J.K. Aase, and V.L. Cochran. 2004. Water use and biomass production of oat-pea hay and lentil in a semiarid climate. Agron. J. 96:298-304.

Raun, W.R., and G.V. Johnson. 1999. Improving nitrogen use efficiency for cereal production. Agron. J. 91:357-363.

SAS Institute. 2003. Release 9.1. SAS Inst., Cary, NC.

Shah, N.H., and G.M. Paulsen. 2003. Interaction of drought and high temperature on photosynthesis and grain-filling of wheat. Plant Soil 257:219-226.

Stamm, M.M., C.S. Schauer, L.M.M. Surber, S.D. Cash, and A.L. Todd. 2006. Profitable calf background integrating annual forage crops. Proc. West. Soc. Am. Soc. Anim. Sci. 57:343-345.

Struick, P.C., and F. Bonciarelli. 1997. Resource use at the cropping system level. Eur. J. Agron. 7:133-143.

Strydhorst, S.J., J.R. King, K.J. Lopetinsky, and K.N. Harker. 2008. Forage potential of intercropping barley with faba bean, lupin, or field pea. Agron. J. 100:182-190.

Todd, A.L., L.M.M. Surber, S.D. Cash, M.M. Stamm, C.S. Shauer, and M.M. Thompson. 2007. Backgrounding calves with cereal forage crops. Proc. West. Sect. Am. Soc. Anim. Sci. 58:344-347. 